\begin{tabular}{lll} 
Review Article & $\begin{array}{l}\text { Yönetim, Ekonomi, Edebiyat, } \\
\text { İslami ve Politik Bilimler } \\
\text { Dergisi,3(1): 164-190, }\end{array}$ & $\begin{array}{l}\text { JOMELIPS - Journal of } \\
\text { Management Economics Literature } \\
\text { Araştırma Makalesi }\end{array}$ \\
DOI: 10.24013/jomelips.437418 & 30 Haziran/June, 2018 & e-ISSN :2547-9512 \\
\hline
\end{tabular}

\title{
Terör Saldırılarının Haberleştirilmesinde Gazete Yayın Politikalarının Etkisi
}

\author{
Dr. Öğr. Üyesi Abdülkadir GÖLCÜ̈ ${ }^{*}$ \\ ${ }^{1}$ Selçuk Üniversitesi, İletişim Fakültesi, Gazetecilik Bölümü, kadirgolcu@selcuk.edu.tr \\ Dr. Emre Osman OLKUN² \\ ${ }^{2}$ Selçuk Üniversitesi, İletişim Fakültesi, Gazetecilik Bölümü, emreolkun@selcuk.edu.tr \\ Öz
}

Medyanın terörün temsilinde kullandığı dil ve söylem toplumsal uzlașıyı sağlamaya, barışın tesis edilmesine yönelik olabildiği gibi kamuoyunda infial yaratacak ya da terörizmin amacına hizmet edecek şekilde de kurgulanabilmektedir. Bu çalışmanın amacı medya kuruluşlarının benimsemiş oldukları yayın politikaları ve ideolojik yapılarının terör haberlerinin sunumunda kullanılan dile ve haber söylemlerine yansımasını ortaya koymaktır. Bu bağlamda 10 Ekim2015' te Ankara Garı'nda ve 13 Mart 2016'da Ankara Güvenpark' ta meydana gelen bombalı terör saldırılarının aktarımda belirlenen gazetelerin üretmiş oldukları haber söylemleri terörün temsili üzerinden analiz edilmiştir. Çalışmada yöntem olarak Teun van Dijk'in geliştirmiş olduğu söylem analizi yöntemi kullanılmıştır. Türkiye'de sosyalist yayın politikalarına sahip Evrensel ve Birgün gazetelerinde bu iki olayla ilgili yayınlanmış olan haberlerdeki terörle ilgili söylem yapıları analiz edilmiştir. Analizler sonucunda elde edilen bulgular; ele alınan gazetelerin her iki terör saldırısının haberleştirilmesinde kullanmış oldukları söylem pratiklerinin, çecçevelerinin ve yapılarının farklılık arz ettiğini ortaya koymaktadir.

Anahtar Kelimeler: Terör, Haber Söylemi, Genel Yayın Politikası, Söylem Analizi 


\title{
The Effect of Newspaper Publication Policies on Turning Terror Attacks into News
}

\begin{abstract}
The language and discourse that the media uses to represent terrorism can be designed to provide social reconciliation, to establish peace, as well as to create irritation in public or to serve terrorism purposes. The aim of this study is to reveal the reflection of the publishing policies and ideological structures adopted by media organizations to the language and news discourse used in the presentation of news about terror attack. In this context, the statements made by the newspapers determined by the bombed terrorist attacks in Ankara Güvenpark on October 10, 2015 and the Ankara Gazi on March 13, 2016 were analysed on the basis of terror attacks' presentation. In the study, the discourse analysis method developed by Teun van Dijk was used. Discussions on terrorism related to these two events in the newspapers Evrensel and Birgün, which have socialist publishing policies, have been examined. As a result of the analyses, it became clear that the practices, the frames and the structures of the discourse that the newspapers used in turning the two terrorist attacks into news are different.
\end{abstract}

Keywords: Terrorism, News Discourse, General Publication Policy, Discourse Analysis

\section{Giriş}

Terörizm; dünden bugüne birçok toplumun tarihsel anlamda tecrübe etmek zorunda kaldığı evrensel bir sorun olagelmiştir. Latin kökenli olan kavram "terrere" kelimesinden türemiş ve "dehşet", "korkunç şey", "dehşet saçan kimse veya şey" şeklindeki ifadeleri karşılamak için kullanılmıştır (Korkmaz, 2006: 5). Modern çağın başlangıcından bugüne kadar geçen sürede ise terör kelimesi ve terörizm hızlı bir dönüşüm süreci yaşamıştır. Bu süreçte çeşitli biçim ve yapılarda ortaya çıkan terör örgütlenmeleri zaman içerisinde etki alanlarını arttırmış ve daha kompleks bir etkileme potansiyeline sahip olmuşlardır. Bugün gelinen noktada terör örgütleri günümüzün tehdit ve tedirginlik kaynağı olmayı başarmıştır (Bal, 2006: 1-2). Terör Türkiye için de tarihsel bir bağlamda tecrübe dilmek zorunda kalan ve bugün de etkisini devam ettiren 
çok yönlü bir süreç olarak kabul edilmektedir. Türkiye yakın tarihin son 50 yılında terör faaliyetlerinin yoğun olarak gerçekleştiği, gerçekleşen bu terör eylemleri sonucunda birçok masum insanın hayatını kaybettiği, ülke ekonomisinin ağır bedeller ödediği ve birçok sosyal sorunla yüzleşmek zorunda kalınan bir ülke olarak görülmektedir.

Terörizmin olmazsa olmazı siyasal amaç taşıyan şiddet eylemleridir. Siyasal şiddet türlerinden biri olarak terörizmde amaç gerçekleştirilen sembolik şiddet eylemleri sayesinde medyada yer bulmak ve medya aracılığı ile terör örgütünün propagandasını yaparak örgütün ideolojisini, gücünü ve varlığını ortaya koyup kamuoyunda korku, ümitsizlik ve panik havası oluşturmaktır. Kuşkusuz bu amaçları gerçekleştirmede faydalanılmak istenen en önemli araç medya olarak kabul edilmektedir. Bu bağlamda terörizm; eylemselliğini medyatik bir düzleme taşıma ya da medya doğasının gereklerine uygun saldırılar planlama yönünde tercihler yapmaktadır. Bunun yanı sıra terör eyleminin kendisi de bir mesaj niteliği taşımaktadır. Bu mesajın dünya genelinde hızlı bir şekilde yayılarak büyük kitlelerin dikkatinin çekilmesi, terör örgütlerinin nihai hedefleri arasında yer almaktadır (Özdemir, 2016: 239). Bütün terör örgütleri çeşitli eylemler gerçekleştirip toplum içerisinde korku, ümitsizlik, panik, kaos gibi yoğun duygusallıklar ya da karmaşalar oluşturarak kendi ideolojik hedeflerine ulaşmaya çalışmaktadır. Kamuoylarında oluşacak bu havanın etkisiyle siyasal iktidarlara olan güven zedelenecek ve dolayısıyla kamuoyunun oluşturacağı baskıya kayıtsız kalamayacak olan meşru siyasal iktidarlar toplumsal uzlaşıyı sağlamak, barış ve huzuru yeniden tesis etmek için terör örgütünün amaç ve hedefleri doğrultusunda politikalarını yeniden gözden geçirecektir. Bu bağlamda siyasal bir azınlığın iradesi hiçbir meşruiyeti ve yasal dayanağı olmayan terörist şiddetin yıldırıcı etkisi ile ihtilalci bir nitelik kazanarak çoğunluk iradesine dayatılacaktır.

\section{Amaç}

$\mathrm{Bu}$ çalışmada; gazete yayın politikalarının terör saldırılarının haberleștirilmesinde kullanılan haber dili ve haber söylemine etkisini ortaya çıkarmak amaçlanmıştır. Bu doğrultuda gazete yayın politikalarının haber söylemlerine etkisi 
terör saldırıları ekseninde analiz edilerek, ortaya konacaktır. $\mathrm{Bu}$ amaç doğrultusunda gazete yayın politikalarının ve terör saldırılarını gerçekleștiren faillerinin ideolojik eğilimleri arasında benzerliklerin olduğu durumlarda; terör gibi evrensel problemlerin sunumlarındaki sorunlu yapılar da ele alınacaktır.

\section{Kapsam}

Çalışma kapsamında terör saldırılarının haberleștirilmesinde gazete yayın politikalarının haber söylemine ve terör saldırılarının sunumuna yapmış olduğu etkisi üzerinde durulacaktır. Bu bağlamda özellikle belirlenen konu üzerinden haberleștirilen terör saldırılarının aktarımındaki haber söylemleri, haberler için kullanılan çerçeveler ve aktarım cümleleri üzerinden genel söylemsel yapı ele alınacaktır. Bu kapsamda sosyalist yayın politikalarına sahip Birgün ve Evrensel gazetelerinin yayın politikaları ve bu politikaların terör örgütleri PKK'nın ve DEAŞ'ın gerçekleştirmiş olduğu terör saldırılarını ele alışı tartışılacaktır. Bu çalışma; terör saldırılarının haberleştirilmesinde ideolojik eksende belirlenmiş olan yayın politikalarının benzer olayları farklı bağlamlar ve söylemlerde ele aldığını ortaya koymaktadır. Bu bağlamda gazete yayın politikalarının haber üretim süreçlerine yapmış olduğu etki ortaya çıkarılacaktır. Bu nedenle bu çalışmanın alana özgün bir bakış açısı ve katkı yapacağı görülmektedir.

\section{Araştırmanın Yöntemi ve Sınırlılıkları}

$\mathrm{Bu}$ araştırmanın yöntemini oluşturan söylem analizi; güç, hâkimiyet, hegemonya, sınıf farkı, cinsiyet, ırk, ideoloji, ayrımcılık, çıkar, kazanç, yeniden oluşturma, dönüştürme, gelenek, sosyal yapı ya da sosyal düzen gibi temaları ön plana çıkaran ve ortaya koyan bir yaklaşım üzerinden işleyiş göstermektedir. Bu bağlamda söylem analizi güç ilişskileri, değerler, ideolojiler, kimlik tanımlamaları gibi çeşitli toplumsal olguların dilsel kurgulamalar yoluyla bireylere ve toplumsal düzene nasıl yansıdığı ve nasıl işlendiği ile ilgilenir (van Dijk, 2003). Söylem analizi ile amaçlanan medya tarafından üretilen haberlerin ve metinlerin söylemleri ile anlamı nasıl inşa ettikleri ve nasıl yorumladıklarını ortaya çıkarmaktır. Bu doğrultuda Teun A. van Dijk 
haber söyleminin analizini sistematize ederek, haber anlatısını sentaktik ve semantik olmak üzere iki dilsel çözümleme türünde ele almıştır. Sentaktik çözümlemede, analiz birimi olarak haber metninde kullanılan cümlelerin gramatik yapılarına odaklanırken, semantik çözümlemede ise sözcüklerin, cümlelerin, kısaca bütün söylemin anlamı üzerinde durulması öngörülmektedir (van Dijk, 1988: 15). Bu bağlamda sentaktik çözümleme sonucunda gazetelerin haber metinlerinde kendi ideolojisi doğrultusunda gerçekleșen olumsuz eylemlerin aktarımında edilgen cümle yapıları kullanarak olumsuzluğun ve aktörünün gizlenmeye çalışıldığı, ideolojisine aykırı gerçekleșen olumsuz eylemlerin aktarımında etken cümle yapıları kullanarak olumsuzluğun aktörünün ve faillinin öne çıkarıldığı görülmektedir. Dolayısıyla 'biz' olarak görünenlerin olumsuzlukları örtülürken 'onlar' olarak görünenlerin olumsuzlukları öne çıkarılmaktadır (İnal,1996: 154).

Teun van Dijk'ın söylem çözümlemesi modeli makro yapının ve mikro yapının ayrı ayrı çözümlendiği iki ana bölümden oluşmaktadır. Makro yapı incelemesi haber anlatısında işlenen temayı yansıtan ve haber üretiminde kullanılan șemanın incelenmesi olarak tematik ve şematik olmak üzere iki aşamada geçekleştirilir. Öncelikli olarak üst başl1k, başlık, alt başlık, spot ve haber girişlerinin çözümlenmesi tematik aşamayı oluşturur ve bu aşamada yer alan başlık ve spotlar aracılığı ile okuyucu kitle haberi beli bir görüş çerçevesinde okumaya yönlendirilir. Makro incelemenin ikinci aşamasını oluşturan şematik yapı ise ana olay, haber kaynakları, ardalan ve bağlam bilgisi, olayın taraflarının yorumları/değerlendirmeleri, fotoğraflar vb. unsurlardan oluşur ve haberde gerçekleşen olayın arka planına ilişkin bilgileri içererek haber aktörlerinin yorumlarına yer vermektedir. Şematik inceleme sayesinde gerçekleşen olaya dair bilgilerin ideolojik izleri görülebilmektedir. Mikro yapı çözümlemesi üç aşamadan oluşur. İlk aşamada sentaktik çözümleme ve bölgesel uyum ele alınarak cümlelerin etken ve edilgen yapısı ile birlikte oluşturulan haber cümlelerinde okur ile gazeteci arasındaki kültürel ve ideolojik bağ incelenir. Bölgesel uyum olarak adlandırılan çözümlemede ise haber metninde ardı ardına gelen cümleler arasında oluşturulmaya çalışılan nedensel, işlevsel ve referansal ilişkiler ortaya çıkarılmaya çalışılmaktadır. İkinci aşamada sözcük seçimleri ele alınır ki bu aşamada haber söyleminde tercih edilen sözcüklerin taşıdı̆̆ 
anlamların ideolojik ve kültürel anlamları çarpıcı veriler edinmeyi sağlamaktadır. Son aşamada ise retorik çözümlemeler yapılmaktadır. $\mathrm{Bu}$ aşamada haber metnin inandırıcılığını artırmak ve okuyucunun ana temayı içselleştirmesini sağlamak amacıyla kullanılan kafiye, abartma, küçümseme, mecaz, çağrışım, kıyas, zıtlıklar gibi anlatım özellikleri, fotoğraflar, sayısal veriler ve alıntılar incelenir. Bu unsurlarla kurulan haber söylemi sayesinde gerçekleşen olay enformasyon vermekten çok üstü kapalı şekilde ideolojik boyuta taşınır ve söylenenin ardında gizlenerek söylenmek istenen iletilir (van Dijk,1988: 19-38; 2007: 170).

Dolayısıyla gazetelerin haber metinlerinde söylenenden çok söylenmeyenleri okuyabilmek, görebilmek ve anlayabilmek amaciyla çözümleme yapma gereği ortaya çıkmaktadır. Bunu gerçekleştirebilmenin en etkili yolu ise söylem analizi yöntemidir. $\mathrm{Bu}$ yaklaşım aracılığıyla yayın politikalarını sosyalizm düşüncesi üzerine inşa etmiş olan Evrensel ve Birgün gazetelerinin Ankara'da yaşanan iki farklı terör saldırısı karşısında inşa ettikleri haber metinlerinde kullandıkları dil ve söylem incelenerek, gazetelerin yayın politikalarının terör haberlerinin temsiline yapmış olduğu etki anlaşılmaya çalışılmıştır. Bu çalışma doğrultusunda gazeteler tarafından oluşturulan haber metinlerinde mevcut kodlamalar çözülmeye çalışılarak gazetenin yayın politikasının haber metinleri ve haber söylemleri üzerindeki etkisi sergilenmeye çalışılmıştır. Çalışmanın zaman sınırlılığı; terör saldırılarının yoğun olarak haberleștirildiği saldırılardan sonraki ilk gün olarak belirlenmiştir. Ayrıca gazetelerin konuyla ilgili manşet olarak yayınladıkları ana haber ve bu haberin iç sayfadaki devamı üzerinden analizler yapılmıştır.

\section{Araştırmanın Problemi}

$\mathrm{Bu}$ araştırma gazete yayın politikalarının haber söylemine etki ettiği, haberin temel gerçekliğiyle uyuşmayan söylemler üreterek dolaşıma soktuğu kabulüne göre tasarlanmıştır. Bu problem ekseninde özellikle gazete yayın politikalarının terör gibi evrensel bir suçun sunumunda bile çeşitli ideolojik dayanaklardan kaynaklı farklı temsillere sebep olduğu görülmektedir. Bu bağlamda gazete yayın politikalarının haber 
söylemine etki ederek, evrensel düzeyde suç olan bir fenomeni bile çarpıtabileceği, bu tip durumlarda izler/okur kitleyi yayın politikası ekseninde olayları okumaya ve kavramaya neden olmaktadir.

\section{Kuramsal Çerçeve}

\section{Medyada Ve Terör}

Terörizm bu amaç ve hedefleri doğrultusunda medyada sıkça yer almak ister ve terörist eylemlerini planlama ve gerçekleştirme aşamasında medyayı ve onun üreteceği etkiyi hiçbir koşulda göz ardı edemez. Çünkü medya terörün yaşam kaynağı ve oksijeni olmakla birlikte geniş kitlelere ulaşabileceği, propagandasını yapabileceği ve hedeflerine ulaşabileceği en önemli araç olarak kabul edilmektedir. Medyanın teröristlerin propagandası açısından taşıdığı bu önem, modern zamanlarda teröristler tarafından bir silah olarak algılanmasına ya da tanımlanmasına bile yol açmıştır (Combs, 1997: 143). I. Dünya Savaşı sırasında Alman General Erich Ludendorff'un “Artık savaşlar silahla değil sözcüklerle yapılıyor. Silahı değil sözü iyi kullanan savaşı da kazanır" (Devran, 2015: 85) sözündeki gerçekliğin farkında olan terör örgütleri kendilerini meşru gösterebilmelerinin en etkili yolunun medya olduğunun bilincindedir. $\mathrm{Bu}$ durumu fark eden ulusal güvenlik örgütlenmeleri; medyatik terörün önüne geçebilme adına çeşitli stratejiler ve yöntemler geliştirerek önleyici tedbirler almayı gerekli görmüştür. Dolayısıyla geleneksel ve sosyal medyanın hatta toplumun dikkatinin nasıl çekileceği konusu, terör örgütleri için eylemin kendisini planlamaktan daha da önemli bir hal almıştır. Çünkü terör eyleminin ve yol açtığı sonuçların hızla kitlelere ulaştırılması, eylemin günlerce kamuoyunu meşgul etmesi söz konusu örgütler için hayati bir önem arz etmektedir (Devran, 2015: 85). Bu doğrultuda düşünüldüğünde medyanın ve kamuoyunun dikkatini çekmeyi başaramayan bir terör eylemi, başarısız olarak kabul edilmektedir.

Terör eylemlerinin medyada yer bulmasının ne denli önemli olduğu gerçeği bir kenara bırakıldığında, bu olayların medyada nasıl ele alındığı ve terörün medyada nasıl temsil edildiği de önem arz etmektedir. Toplumun geneli tarafından fazlasıyla dikkate 
alınan bu tip olaylara medyanın yaklaşımı, bakış açısı ve sunuş biçimi gibi bazı konu başlıkları çeşitli yönlerden ele alınmak zorundadır. Öncelikle terör eylemlerinin haberleștirilmesi ulusal ve uluslararası güvenliğe yönelik tehditler içermesi nedeniyle önemlilik arz etmekte ve bu durum da bir haber değeri olarak evrensel düzeyde kabul görmektedir. Fakat gazetecilik mesleğinin evrensel düzeyde kabul edilmiş olan kuralları gereğince; teröre çağrı yapmak, teröristi övmek ya da meşrulaştırmak, terör eylemlerini olumlamak gibi davranışların ifade hürriyeti kapsamına girmediği kabul edilmektedir (T11ıç, 2001). Bu noktada terörün haberleştirilmesi, haber metni için tercih edilen durum tanımlamaları, dil yapısı, söylem ve çerçeveleme gibi birçok faktör önem kazanmaktadır. Haber medyasının toplumsal olayların sunumu sürecinde sadece bilgi verme işlevi olmadığı, bunun yanında insanları siyasallaştırma, eğitme, toplumsallaştırma gibi çok geniş bir yelpazede etkisi altına aldığı kabul gören bir gerçektir. Haber medyası toplumsal güç ve iktidar ilişkilerinin kurulduğu, pekiştirildiği, dolaşıma sokulduğu, yeniden üretildiği ve meşrulaştırıldığ 1 bir mekanizma işlevlerini yerine getirmektedir (Karaduman ve Batu, 2011: 359).

Avşar ( 2009: 83) terör olaylarının bir haber değeri taşıdığı, okur/izleyici kitle tarafından öğrenilmesi ve bilgilenilmesi gerekli olaylar olduğunu vurgulamaktadır. Medya yüksek haber değeri taşıyan terör eylemlerine yer vermekte ve medyanın modern toplumlardaki önemli işlevlerinden biri olan kamuoyunu aydınlatma ve bilgilendirme işlevini yerine getirmektedir. Nitekim Topçuoğlu (1992) tarafindan yapılan araştırmaların bulguları, medyada haber olan konular arasında terör haberlerinin en çok okunan ve izlenen haberler olduğunu ortaya koymaktadır. Dolayısıyla medya; en çok okunan ve izlenen haberlere yer vererek hem toplumsal işlevini yerine getirmekte hem de kendisi için hayati önem arz eden baskı sayısı ve reyting kaygılarını gidermiş olmaktadır. Bu noktada terör örgütleri ile medya örgütlenmeleri arasında farkında olmadan oluşmuş karşılıklı bir çıkar ilişkisi olduğu görülmektedir. Dolayısıyla medya ve terörizm arasındaki ilişkiyi karşılıklılık esasına dayanan ortak bir yaşam çabası olarak tanımlanmak doğru olacaktır. Bu ikili arasındaki ilişki kısa süreli olarak görülürken, uzun vadede ifade özgürlüğü gibi çok geniş bir bağlam üzerinden medyanın 
terör örgütleri tarafından kullanılması, demokratik toplum yapısının da zarar görmesine neden olmaktadır (Schaffert, 1992: 87).

Terör olaylarının medyada sunumu söz konusu olduğunda; bu olayların detaylıca analiz edilerek aktarılması yerine, medyanın doğasına uygun bölümlerin, görüntülerin ya da bilgilerin yinelenmesine dayanan bir sunumun gerçekleştirildiği görülmektedir. Özellikle haber medyası; terör olaylarının ilgi çekici yönü olan görselliği ön plana çıkartarak, yaşanan olayları halkın anlayabileceği bir basitleştirme süzgecinden geçirerek kamuoyuna sunmaktadır. Dolayısıyla toplumun terör olayları ile ilgili temel bilgi alma kaynağı olarak medya önemli bir görevi üstlenmektedir. Toplumun kitle iletişim araçları ve medyaya olan güveni göz önüne alındığında, terör haberleri gibi toplum üzerinde büyük etkiye sahip haberlerin sunulmasında üst düzey bir dikkate ihtiyaç olduğu da bu bakış açısından hareketle ayrıca hatırlanmalıdır (Yücel, 2011: 49). Çünkü böyle durumlarda medya kendi doğasına uygun bir şekilde kamu yararından da hareketle kendi çıkarlarına ulaşmak için çeşitli yöntem ve teknikleri kullanmaktan çekinmezken; terör örgütleri de medya aracılığı ile eylemlerini toplumsal süreçte etkili söylemlere dönüştürmeyi planlamaktadır. Bunun yanı sıra terör örgütleri medya aracılığıyla, siyasal iktidarı sarsmak, otoriteyi zayıflatmak, kendini güçlü göstermek, halk1 korkutmak, örgüt üyelerine moral vermek, güvenlik kuvvetlerini yasal sınırların dışına çıkarmaya çalışmak ve siyasi alanda kendisini bilinir kılmak adına çeşitli beklentiler içerisinde olmaktadır (Korkmaz, 1999: 232). Bu nedenle de terör haberlerinin medyada yer almasından çok, medyanın terör haberlerini sunarken, inşa ederken kullanmış olduğu dil, haber söylemleri, çerçeveler ve bütün bu süreçler üzerinde etkili olan yayın politikaları önemli bir tartışma konusunu oluşturmaktadır.

\section{Gazete Yayın Politikaları ve Haber Söylemi Üzerindeki Etkisi}

Bugün yoğun olarak endüstriyel ilişkiler tarafından etki altına alınmış olan medya sektörü, bu ilişkilerden kaynaklanan çeşitli yapısal dönüşümlere maruz kalmaktadır. Bu duruma en iyi örnek modern gazeteciliğin bürokratik yapılanması, örgütlenmesi ve sektörde bir aktör olarak varoluş nedeni; gazete çalışanlarının mesleki kuralları ve ahlaki değer yargıları üzerinde doğrudan şekillendirici olmakta ve alternatif değer yargılarına medya sektöründe kesinlikle yer bırakmamaktadır. Alternatif bir 
anlatının gelişmesine izin verilmeyen böylesi medya örgütlenmelerinde habere dair bilgi ve belgelerin toplanması, işlenmesi ve yayına hazırlanması yazı işleri ve haber merkezi olarak adlandırılan bir takım profesyonelin süzgecinden geçerek profesyonelliğin belirlediği endüstriyel bir düzlemde gerçekleşmektedir. Öncelikle her yazı işleri sorumlusunun üstünde yetkilerini sınırlayan bir gazete sahibi, yayınevi yöneticisi ya da genel yayın yönetmeni vardır- şayet yazı işleri sorumlusu güçlü bir kişilikse ve başarılı ise, gücü kısmen sınırlanır ve gazete sahibi basın-yayın konusunda fazla hırslı ise ve gazetenin gidişatını da iyi görmüyorsa, o zaman tamamen kısıtlanabilir; ya da ikisi arasında bir yerdedir (Schneider ve Raue, 2002: 164). Basının böylesine yoğun bir şekilde endüstriyel süreçlere eklemlenmesi, "yayın bağımsızlığı" ve "basın ahlak ilkeleri" gibi birçok evrensel kriterin medya şirketleri adına yeniden yorumlanmasına da neden olmuş; basın ahlakı ve özgürlüğü medya şirketinin çıkarları doğrultusunda çevrelenmiştir. Dolayısıyla normal koşullarda "yayın bağımsızlığı" olarak ifade edilen kavram doğrultusunda, gazetenin yayın politikasının profesyonel gazeteciler tarafından ve gazetecilik önceliklerine göre saptanması gerekmektedir. Fakat bu durumun pratiği daha faklı uygulanmakta ve işletme rasyonalitesi yayın politikası üzerinde esas belirleyici olmaktadır (Arık, 2006: 34).

$\mathrm{Bu}$ süreçte haberin hammaddesi yayın örgütlenmesinin benimsemiş olduğu politik ve ideolojik çerçevelere uygunluk sürecinden geçirilerek "strelize" edilmektedir. $\mathrm{Bu}$ duruma ilişkin olarak haber örgütlenmelerinde muhabirinden, genel yayın yönetmeninde kadar habere etki eden her aşama haberde ne kadar bilgiye, nasıl ve ne doğrultuda yer verileceğini belirleyen "ideolojik bir kare" olarak değerlendirilir. Bir başka anlatımla; haber üreticileri kendilerinin olumlu ötekilerin ise olumsuz tarafları hakkında çok söz söylerken, kendi olumsuzlukları ve öteki için olumlu olan konularda ise az şey söylemeyi tercih etmektedirler (Devran, 2010: 81). Çünkü haber söylemleri ve haber üretim süreçlerinde tercih edilen yöntem, çerçeve ve dil genellikle haber örgütlenmelerinin yayın politikalarından bağımsız bir süreçte gelişme gösteremez. Dolayısıyla haber medyasının benimsemiş olduğu yayın politikasına göre, tercih ettiği ya da temsil sürecinde uygulamak istediği bazı aktarım yöntemleri; terör olaylarının da sunumunda etkili olabilmektedir. 
Shoemaker ve Reese (1996) gazetecilerin haber yapma süreçlerindeki kararlarına ilişkin etkileri mikro düzeyden makro düzeye doğru "Etkiler Hiyerarşisi" modeli üzerinden açıklamaya çalışmıştır. Modele göre bir şahıs olarak medya çalışanından kaynaklanan etkiler, haberin oluşturulduğu yapı, gazetecilik mesleki normları ve pratiklerinden kaynaklanan etkiler, medyanın kendi kurumsal yapısından kaynaklanan etkiler, medya dışından kaynaklanan etkiler, ideolojik yapıdan kaynaklanan etkiler olarak çeşitli başlıklar altında ele alınmaktadır. Bu sıralanan başlıklar arasında; medyanın kurumsal yapısından kaynaklanan etkiler ve bu kurumsal yapının işleyişinde oldukça etkili olan ideolojik yapıdan kaynaklanan etkilerin ne kadar belirleyici olduğu bir kez daha görülmektedir. Shoemaker ve Reese'in medyanın kurumsal yapısı başlığı altında ele almış olduğu ekonomik ilişkiler ağının da gazete yayın politikaları üzerinde oldukça belirleyici olduğu unutulmamalıdır. Bu doğrultuda önemli bir örnek olarak Rupert Murdoch'un İngiltere'de London Times gazetesini satın aldıktan sonra, gazetenin yazı işleri çalışanlarına yayın politikası hakkında sözlü ve yazılı talimatlar verdiği bilinmektedir. Bu talimatların yerine getirilmemesi ve London Times gazetesi editörlerinin büyük bir çoğunluğunun bu olaydan ötürü istifa etmesi sonrasında "bu kadar yolu gazetenin işlerine karışmamak için mi geldim" ifadesini kullanması, gazete yayın politikası üzerindeki sahiplik yapısı etkisini kanıtlamaktadır. $\mathrm{Bu}$ doğrultuda gazete çalışanları yayın politikasına uyumlu bir ideolojik perspektifle seçilerek, gazete ekibi oluşturulmaktadır. $\mathrm{Bu}$ bağlamda gazete yayın politikaları üzerinden konu detaylıca ele alındığında, habere konu olan eylemlerin failleri ve haber örgütlenmeleri arasında ideolojik yakınlıkların olduğu durumlarda; terör saldırılarının haberleştirilmesi yayın politikası doğrultusunda ideolojik bir eğilim kazanmaktadır.

Bir başka örnekte İngiliz Mirror grubunun patronu Robert Maxwell neredeyse bütün gazetelerin yayın politikasını bizzat kendisinin belirlediğini dile getirmektedir. $\mathrm{Bu}$ durum için kullanmış olduğu şu cümle de oldukça manidardır: "Bu işe doksan milyon pound yatırdım ve bunu dua almak için yapmadım. Bu işin sahibi benim. Patron benim" (Duran, 1999: 192). Robert Maxwell'in Mirror grubuyla yaşamış olduğu bu durum, başka örneği görülmeyen bir olay olsaydı bir dipnot olarak kalırdı. Oysa sadece 
İngiltere özelinde bile basın özgürlüğü kavramının dalgalı bir geçmişi ve belirsiz bir geleceği olduğu bilinmektedir. Basın özgürlüğünün temelinde bulunan yayımlama hakk1, gazete sahipliğine bağlıdır ve editoryal bağımsızlıkla ilgili bir hüküm bulunmamaktadır. Daha anlaşılır şekilde yayına hiç müdahale etmeyen bir yaklaşımı ve yayın politikasını benimseyen bir gazete sahibi bulunmamaktadır (Hanlin, 1998: 57). $\mathrm{Bu}$ bağlamda medya içeriğinin ve özellikle gazete yayın politikalarının varolan ekonomik ve politik yapı karşısından oldukça kırılgan ve etkiye açık olduğu görülmektedir. Bu noktadan hareketle ekonomi-politik yaklaşım medya kuruluşlarının ürettiği ve aktardığı metinlere etki eden temel unsurları merkezine alarak; medya kurumlarının mülkiyet yapılarına bakmadan medya içeriğinin nasıl oluştuğunu anlamaya çalışmanın eksik bir çaba olacağını dile getirmektedir.

Bugün modern haber örgütlenmelerinde yayın politikası adı altında geliştirilmiş olan denetim politikaları, profesyonel gazetecilik pratiklerinin habercilik çalışmalarında kullanılmasının güvencesi olarak sunulmaktadır. $\mathrm{Bu}$ durumun bir sonucu olarak editörler ve medya sahipleri, gazetecilerin kendileri açısından başarılı ve saygı değer olabilmeleri için izlemeleri gereken rehberlik ilkelerini geliştirdiklerini iddia etmektedir (Bennett, 2000: 315). Küçüközyiğit'e (2014: 28) göre de gazetelerde her gün düzenli olarak yapılan haber toplantıları; haber üretim sürecinde, mesleki kararların yoğunlaştığı önemli aşamalarından biri olarak kabul edilmektedir. Haber üretimi hakkındaki kişisel gündem ve tercihlerin dile getirildiği bu toplantılarda haber kararları ve mesleki kararlar, yayın politikasının da etki ettiği bir zeminde şekillenir, somutlaşır. Bu anlatıdan hareketle yayın politikası haber toplantılarının yapılacağı temel zemini şekillendirerek, esasında haberin üretim sürecine ve habercinin haberi algılama biçimine doğrudan olmasa bile dolaylı bir şekilde fakat güçlü bir potansiyelle etki etmektedir. Mesleki olarak konu ele alındığında; bir gazetecinin ya da muhabirin temel hedefi, yaptığı haberin gazetede yayınlanmasıdır. Hangi haberin yayınlanıp yayınlamayacağını belirleyen ise gazetenin Genel Yayın Yönetmeni, Yazı İşleri Müdürü gibi görevlerinde bulunan kişiler, ama en nihayetinde gazetenin genel yayın politikasıdır. Muhabir zamanla neyin haber olarak yayınlanıp neyin yayınlanmayacağını anlar ve ona göre haber yapmaya başlar. Dolayısıyla aslında muhabirin habere bakış açısı da çalıştığı 
kuruma göre belirlenir (Demir, 2013: 150). Ankara'da faal olarak gazetecilik yapan on beş farklı kişi ile görüşülerek medya ve iktidar ilişkilerinin gazetecilik pratikleri üzerine etkisinin araştırıldığı bir akademik çalışmada ortaya çıkan sonuç da bu çalışmanın iddiasını destekler niteliktedir. Demir (2013) tarafından yapılan bu çalışmada; gazetecilerin habere bakış açılarının ve dolayısıyla haber yapma pratiklerinin çalıştıkları kurumların yayın politikasına göre belirlendiği görülmektedir. Kavoğlu'nun (2017: 214) yaptığı bir başka çalışmada ise gazetelerin mülkiyet yapısının ve ideolojik çizgisinin haberin çerçevelenmesinde yadsınamaz bir paya sahip olduğu bulgulanmıştır. Sonuç olarak haber endüstrisinin bürokratik örgütlenmesi içinde gazeteciden beklenen; editörler, haber müdürleri, genel yayın yönetmeni ve medya sahibinin yönlendirmeleri ile oluşturulan genel yayın politikasına en uygun haber metinlerini mükemmel şekilde hazırlamasıdır.

Konuyu kültürel çalışmalar yaklaşımı ekseninde ele alan bir grup düşünür ise, medya içeriğinin zaten belirli ideolojik ilişkiler üzerinden üretildiğini ve bu bağlamda haber özelinde özgün ve bağımsız bir haber üretim sürecinin mümkün olamayacağını dile getirmektedir. Özellikle haber metinlerinin oluşturulmasında ve düzenlenmesinde ideolojik unsurun etkisiyle belli egemen düşünceler, yaklaşımlar ve anlatımlar haber söylemlerinde ön plana çıkarılmaktadır. Dolayısıyla haber metinleri belli dünya görüşünün yansıtıldığı ideolojik ve kapalı bir metin olarak ortaya çıkmaktadır (Yaylagül, 2006: 123-124). Hall ve arkadaşlarının 1978'de yapmış oldukları "Policing the Crisis" isimli çalışmada medyanın "seçici" rolüne işaret edilmektedir. Hall ve arkadaşları medya içeriğinin akredite haber kaynaklarının birebir aktarımlarına uygun şekilde şekillenmediğini aksine medya örgütlenmesinin bu hammadde üzerinde oynayarak; her yayın organının kaynaklardan elde edilen hazır materyali, kendi kriterleri (yayın politikaları) doğrultusunda bir seçim sürecine tabi tuttuğunu dile getirmektedir (Aktaran, İnal, 1994:150). Özellikle televizyon ve gazete haberleri üzerinden aktarılmak istenen ideoloji, medya kuruluşların ait oldukları endüstriyel yapı içerisinde profesyonel pratikler ve egemen norm ve kodlar yardımıyla oluşturulur (Bulut ve Yaylagül, 2004:124). 
Haber ve diğer medya metinleri içinde egemen ideoloji çoğu zaman bu doğrultuda öne çıksa da, haberde yansımasını bulan güç/iktidar ilişkileri yalnızca sınıf ilişkileri bazında açıklanamaz. Dil ve söylem; toplumdaki güç/iktidar ilişkilerinin dayandığı cinsel, etnik, dinsel farklılıkların yansıdığı bir mücadele alanıdır (İnal,1996: 119). Medya kuruluşları tarafindan üretilen haberlerde kullanılan dil ve söylemler medyanın tarafsız ve objektif olmasını engellediği gibi haber metinlerinde medya kuruluşlarının ideolojisinin izlerini de görünür kılmaktadır. Çünkü anlam kendi kendine oluşmaz ve amaçlı olarak inşa edilir. Eagleton'a (2005: 291) göre gerçek durumu dönüştürücü şekilde çalışan ideoloji anlamın toplumsal inşasında medyanın en önemli işlevi olarak karşımıza çıkar. Shoemaker ve Reese (1996: 214) medya içeriği üzerinde etkili olan faktörleri ortaya çıkardıkları çalışmalarında, etki faktörleri arasında yer alan ideolojik düzeyin diğer tüm düzeyleri içine aldığını dile getirmişlerdir. Ayrıca medya içeriği üzerinde etkili olan ideolojik düzeyin toplumdaki çeşitli iktidar odakları yararına çalıştığını belirtmektedirler. Sonuç olarak medya kuruluşları tarafından üretilen haberlerde kullanılan dil ve çerçeveler medyanın doğru bilgi aktarımını engellediği gibi, haber metinlerinde medya kuruluşlarının benimsedikleri yayın politikaları üzerinden meşrulaştırmak istedikleri ideolojileri de görünür kılmaktadır. Ayrıca bu duruma ek olarak medya sahiplik yapısından ve medya-iktidar ilişkilerinden kaynaklanan gerekçeler üzerinden de yayın politikalarını etkileme ve medyanın işletme mantığ üzerinden faaliyet göstermesi de gözden kaçırılmamalıdır.

\section{BULGULAR}

\section{Birgün Gazetesi}

\section{Ekim 2015 Ankara Tren Gar’ı Terör Saldırısı}

Birgün gazetesi Ankara Tren Garı'nda meydana gelen terör saldırısını 11 Ekim 2015 tarihli sayısında geniş bir yer ayırarak ele almıştır. Gazetenin manşetten tam sayfa olarak duyurmuş olduğu haber, iç sayfada da detaylıca işlenmiştir. 


\section{Makro Yapı Analizi:}

Birgün gazetesinin 11 Ekim tarihli sayında yaşanan terör saldırısını "YIKILSIN BU ÖLÜM İKTIDDARI” başlığı altında büyük puntolarda tam sayfa olarak okuyucularına aktarmıştır. Haberde kullanılmış olan “ÖLÜM İKTIDARI” ifadesi, haber söylemi üretmede en önemli unsurlardan biri olan haber başlığı büyük puntolarla aktarılarak, haber söyleminde terör saldırısının sorumluluğunu varolan siyasal iktidara yükleyen bir anlatım sağlamıştır. Gazete haber söylemin inşa için haberin spotunda da benzer bir anlatım tekniği kullanmayı tercih etmiştir. Haber spotunun ilk cümlesinde kullanılmış olan "Suruç’un üzerinden üç ay geçmeden" ifadesi ve yine spotta kullanılmış olan "Polis patlamanın yaşandığı noktaya gaz bombaları ile saldırdı" ve haber görseli üzerinden aktarılan "Polis patlamanın hemen ardından insanlara saldırdı" ifadeleri, bütüncül bir şekilde haber metninde varolan siyasal iktidarı terör saldırısından sorumlu tutan bir söyleminin üretilmesini mümkün kılmıştır. Ayrıca gazete "Suruç'un üzerinden üç ay geçmeden" ifadesini spotta kullanarak; Suruç’ta yaşanan terör saldırısından da yine siyasal iktidarın sorumlu olduğunu ima eden bir anlatı çatısını haber söylemine eklemlemiştir. Haber için tercih edilen görsel kullanımında ise patlama alanından yaralı ve cansız bedenlerin gösterildiği bir görsel tercih edilmiştir. Aynı görselin hemen yanındaki ikinci bir görselde ise olay yerine intikal eden güvenlik görevlilerinin koşarken sunulmuş olması, haberin hem spotunda hem de metninde tekrar edilmiş olan "Polis patlamanın hemen ardından insanlara saldırdı" söylemini destekleyen bir dizayn içerisinde ilk sayfaya yerleștirilmiştir. Ayrıca haber metninin giriş bölümünde ve devamında saldırının muhtemel sorumlusu olabilecek terör örgütleri isimlerinden bilinçli bir şekilde bahsedilmezken, yapılan gösterinin tamamen barışçıl bir amaç doğrultusunda planlandığı ve demokratik amaçlara hizmet ettiği düşüncesi ön plana çıkarılmıştır. Haberin kaynak kullanımı da bu doğrultuda haber söylemini destekleyecek bir yaklaşımla oluşturulmuştur. Haber kaynağı olarak Halkların Demokrasi Partisi Eş Genel Başkanı Selahattin Demirtaş'ın açılmalarına geniş bir alanda yer verilmiştir. Haber için kullanılan ara başlıkta "Karanlık güç yok, aleni güç var" ifadesi Demirtaş'ın açıklamaları arasından ara başlığa taşınmış ve tırnak işareti kullanılmadan aktarılmıştır. Bu başlıktan sonraki ilk cümlede Demirtaş’ın saldırının sorumluluğunu “AKP İktidarı” olarak aktardığı ifadeye geniş bir yer ayrılmıştır. Gazete bu çerçevede haber söyleminde Selahattin Demirtaş'ın açıklamalarını içselleştirerek, 
Demirtaş’1 güvenilir bir kaynak olarak sunmuş ve metinde üretmek istediği siyasal iktidarın terör saldırısından sorumlu olduğu söylemini çeşitli kaynakların aktarımları üzerinden meşrulaştırmak istemiştir. Ayrıca haber metninde konunun ardalan-bağlam bilgisi ekseninde detaylandırılmadan, suçlayan bir anlatıyı ön plana çıkaran kelime tercihleri üzerinden aktarılması da, haber söyleminin meşrulaştırılması için yapılmıștır.

\section{Mikro Yapı Analizi:}

Birgün gazetesinin konuyla ilgili yaptığı haberin sentaktik yapıdan ele alınarak analiz edilmesi sonrasında, haberde tercih edilen aktarım fiillerinin ve kelime yapılarının haber metninde üretilmek istenen söylemi destekleyici şekilde tercih edildiği görülmüştür. Özellikle olayın faili olarak varolan siyasal iktidarın işaret edilmesi ve bu süreçte etken cümle yapılarının kullanılmış olduğu görülmektedir. Terör saldırısını tanımlarken "katliam" kelimesinin ısrarla tercih edilmesi ve bu durumun siyasal iktidar tarafından yapılmıș olduğu iddiasının ön plana çıkarılması, ülkede yapılan bütün terör saldırılarının ardında siyasal iktidarın olduğu düşüncesini ön plana çıkarmaktadır. Gazetenin genel yayın politikasının sosyalist düşünceden etkilenerek şekillenmiş olması, terör saldırısında yaralan ve hayatını kaybeden kişilerin "yurttaş" olarak tanımlanmasına de neden olmuştur. Gazete haber metninde sık sık bu tanımlamayı tercih ederek, yayın politikası doğrultusunda kelime ve tanımlama tercihi yaptığını göstermektedir. $\mathrm{Bu}$ bağlamda haber metninde tercih edilen kelimeler ve bunların kullanılmış olduğu bağlam; haber söyleminin tek yönlü bir anlamsal kapanmayla sonuçlandırılmasına neden olmuştur. Metnin okunmasında alternatif bir alanın açılmamış olması, tek yönlü kaynak kullanımı ve haber için tercih edilmiş olan görseller; bütüncül bir şekilde haber metninde suçlunun varolan siyasal iktidar olduğu retoriğini güçlendirmiştir. Bu durumu güçlendirme adına da imalı anlatımlar yerine; basit, kısa ve doğrudan iddia etme gibi kesin bir dil kullanımı tercih edilerek, haberin retoriğinin de keskin ve belirgin olması sağlanmıştır. Ayrıca haber söyleminde bu retoriğin daha da pekişmesi adına, benzer anlamlara gelen suçlayıcı cümlelerin arka arkaya dizilmesi, dilin sentaksı üzerinden üretilmiş olan suçlayıcı söyleminin haber metni içerisinde pekişmesini sağlamıştır. Bu bağlamda gazetenin bütüncül bir şekilde üretmiş olduğu haber söylemi; 1srarla terör kelimesini kullanmaktan kaçınırken, terör 
saldırısı ya da teröre ilişkin söylemler üretmek yerine saldırıyı gerçekleştireni-eyleyeni ön plana çıkartan bir söylemsel çerçeve üzerine inşa edilmiştir.

\section{Mart 2016 Ankara Güvenpark Terör Saldırısı}

Birgün gazetesi Ankara Güvenpark'ta meydana gelen terör saldırısını 14 Mart 2016 tarihli sayısında geniş bir yer ayırarak ele almıștır. Gazetenin manşetten detaylıca duyurmuş olduğu haber, iç sayfada da detaylıca işlenmiştir.

\section{Makro Yapı Analizi:}

Birgün gazetesinin 13 Mart tarihli sayında yașanan terör saldırısını "KATLİAM" başlığı altında büyük puntolarla ve manşetten okuyucularına aktarmayı tercih etmiştir. Okuyucunun haber metninde ana olayın kurgulanışını tartışmadan okuduğu için; haberin başlığ1, girişi ve olay kurgusu haber söylemini üretmede en önemli unsurlar olarak işlemektedir. Dolayısıyla haber başlığının büyük puntolarla aktarılmasının yanı sıra olay yerinden aktarılmış olan bir görüntünün de haber görseli olarak kullanılmış olması dikkat çekmektedir. Ankara Gar'ında yaşanan terör saldırısında ölü ve yaralıların görselini açık bir şekilde kullanarak bir söylemsel çerçeve dizayn eden gazete, bu haberin görselinde ise yardım ekiplerini içeren bir görseli kullanmayı tercih etmiştir. Ne haber spotunda ne de haber metninin girişinde terör saldırısının gerçekleştiği akşam olayın sorumluluğunu üstlenmiş olan PKK terör örgütü ile ilgili bir bilgiye dikkatle yer verilmediği görülmektedir. Bu bağlamda hem başlık hem spot hem de haber metninin giriş kısmında, terör saldırısı ile ilgili bazı bilgilere yer verilmiş, yaralı sayısı ve olayın etki ettiği alan aktarılmıştır. Haber söyleminde gazete Ankara Gar'ında yaşanan terör saldırısında olduğu gibi "terör" kelimesini kullanmaktan ısrarla kaçınmıştır. Fakat Ankara Gar saldırısında haber söylemini gerçekleștiren-eyleyen üzerine inşa eden gazete, Güvenpark terör saldırısı için aynı söylemsel çerçeveyi inşa etmekten ısrarla kaçınmış, olayı gerçekleştiren-eyleyenle ilişkili hiçbir bilgi haber metninde kendisine yer bulamamıştır. Üretilen haber söyleminde olaya ilişkin ardalan ve bağlam bilgisinden yoksunluk dikkat çekmektedir. Saldırıyı üstlenen PKK'nin daha öncede yapmış olduğu birçok terör eylemi bulunmasına rağmen, haber söyleminde bu konulara ilişkin bilgi 
verilmemesi, terör saldırısının sıradan bir olay gibi haber söyleminde aktarılmasına neden olmuştur. Ayrıca haberde tercih edilen kaynak kullanımı genellikle resmi kaynaklardan yapılan aktarımların gazete yayın politikasına da uygun olanlarının aktarılması şeklinde gerçekleşmiş ve hiçbir siyasinin ya da kanaat önderinin açıklamasına haber metninde yer verilmemiştir. Bu bağlamında haber söyleminde resmi açıklamaların yinelenmesi üzerine inşa edilmiş bir anlatı çerçevesi oluşturulmuştur.

\section{Mikro Yapı Analizi:}

Birgün gazetesinin konuyla ilgili yaptığı haberin sentaktik yapıdan analizi, dikkate değer sonuçların ortaya çıkmasına neden olmuştur. Haber metninde kullanılmış olan kelime tercihleri ve sözcük öbeklerinde özellikle tarafsızlık ve resmi kaynakların aktarımları doğrultusunda bir haber söylemi inşa edilmek istenmiştir. Kelimelerin ve sözcüklerin dizilişi de bu doğrultuda gerçekleşmiştir. Haber metnindeki cümle ve cümlecikler arasında fonksiyonel bir ilişki bulunmakta ve kelime seçimleri aynı zamanda gazetenin içinde bulunduğu sınıfsal konum ve yayın politikasını da yansıtmaktadır. Bu çerçevede gazete terör saldırısından etkilenen insanları "yurttaşlar" tanımı ile aktarmayı tercih etmiştir. Haber başlığı için kullanılan "KATLİAM" kelimesinin metin içinde yinelenmemiş olması, başlık üzerinden belirgin bir söylem üretilmek istenmediğini göstermektedir. Haber retoriği de bu doğrultuda, belirli bir söylemi ön plana çıkarmak yerine; resmi kaynaklardan yapılan aktarımların bazılarını yineleyerek, terör saldırısının failine dair gerçekliklerin gizlenmesini önceleyen bir söylemi ön plana çıkartmıştır. Ankara Gar saldırısının tam sayfa yer ayıran gazete, Güvenpark’ta gerçekleşen terör saldırısı için daha az bir alan tercih ederek sadece manşetten haberi yayınlamıştır. Bu doğrultuda, haber retoriğinde konunun daha sıradan ve detaylandırılmadan aktarıldığı bir anlatı çerçevesinin oluşması kolaylaşmıştır.

\section{Evrensel Gazetesi}

10 Ekim 2015 Ankara Tren Gar'ı Terör Saldırısı 
Evrensel gazetesi Ankara Tren Garı'nda meydana gelen terör saldırısını 11 Ekim 2015 tarihli sayısında geniş bir yer ayırarak ele almıştır. Gazetenin manşetten tam sayfa olarak duyurmuş olduğu haber, iç sayfada da detaylıca işlenmiştir.

\section{Makro Yapı Analizi:}

Evrensel gazetesinin 11 Ekim tarihli sayında yaşanan terör saldırısını "YILDIRAMAYACAKLAR BARIŞ KAZANACAK" başlığı altında büyük puntolarda tam sayfa olarak okuyucularına aktarmıştır. Haberin spotunun ilk cümlesinde yapılan saldırı için "Diyarbakır ve Suruç'tan sonra" ifadeleri ve bu saldırının "ülkeyi kaosa sürükleyen" olarak tanımlanması ön plana çıkarılmıştır. Spotun devamında kullanılan “katliamı protesto için sokağa çıkan binlerce kişinin AKP'yi ve Erdoğan'1 protesto ettiği" ifadesi aktarılmış ve bu ifade üzerinden dolaylı bir anlatımla terör saldırısının sorumlusu olarak haber söyleminde hedef pozisyonuna yerleştirilmişlerdir. Haber için kullanılan görsellerde ise cansız bedenler ve yaralılar açık açık gösterilerek; haber metni içerisinde sık sık kullanılmış olan "katliam" kelimesi üzerinden katliam söylemi ön plana çıkarılmıştır. Haberde olayı gerçekleştiren-eyleyen ile ilgili herhangi bir bilgiye ya da aktarıma yer verilmezken, varolan siyasal iktidarın olayın sorumlusu olduğu haber söyleminde doğrudan anlatım yolları kullanılarak ön plana çıkartılmıştır. Bu doğrultuda haber söylemini güçlendirmek için hem haber metninde hem de haberin spotunda ardalan-bağlam bilgisi kullanılmak istenmiştir. Özellikle Diyarbakır ve Suruç'ta gerçekleştirilen bombalı saldırılara da metinde yer verilerek, varolan siyasal iktidarın bu tür saldırıların sorumlusu olduğu ve terör saldırılarının devam ettirildiği gibi bir düşünce haber söylemi üzerinden aktarılmıştır. Haberde tercih edilen kaynak kullanımı da haber metninde üretilen söylemi güçlendiren bir doğrultuda gerçekleşmiştir. Haber metni içerisinde Emek Partisi Genel Başkanı Selma Gürkan ve Halkların Demokrasi Partisi Eş Genel Başkanı Selahattin Demirtaş'ın açıklamalarına geniş çapta yer verilmiştir. Metinde özellikle haber kaynağı olarak kullanılan Gürkan ve Demirtaş’ın siyasal iktidarı istifaya çağıran ve suçlayan anlatımları ön plana çıkarılmıştır. Bu doğrultuda haber söylemi alternatif kaynaklara ya da açıklamalara kapatılmıştır. Ayrıca haberin genel söylemsel çerçevesine bakıldığında terör ve teröre ilişkin anlatıların aktarımından kaçınılırken, saldırı lanetlenmiş ve katliam olarak tanımlanmıştır. Bu doğrultuda haber 
söyleminin terörü eleştirmek ya da lanetlemek üzerine inşa edilmediği; tam aksine siyasal iktidarı suçlayıcı bir söylemsel çerçeve üzerinden sunulduğu görülmüştür.

\section{Mikro Yapı Analizi:}

Evrensel Gazetesi bu haberin genel söylemsel çerçevesini inşa ederken; suçlayan, hedef gösteren ve sorumluluk yükleyen bir dil yapısını tercih etmiştir. Bu bağlamda haber metnindeki cümlelerin dizilişi ve cümle yapılarında tercih edilen kelime kalıpları yanlı bir dil yapısının oluşmasını kolaylaştırmıştır. Özellikle terör eylemini gerçekleștiren kişilerin ya da terör örgütünün tanımlanması ya da her hangi bir imalı anlatıma maruz bırakılmadan metinde açıkça verilmesi dikkat çekmektedir. Bu bağlamda haber söyleminin mikro yapısında olayın failinin tercih edilen kelimeler ve tanımlama kalıpları sayesinde metin içinde ön plana çıkarıldığı ve hatta varolan siyasal iktidarla ilişkilendirildiği görülmüştür. Ayrıca haber söyleminin üretim sürecinde açıkça hedef gösteren ya da işaret eden anlatımlar üzerinden terör saldırısının sorumlusu siyasal iktidar olarak kesin tanımlamalar sayesinde konumlandırılmıştır. Bu bağlamda haber retoriğinde, tek yanlı bir düşünsel yapı üzerinden terör saldırılarının sorumlusu olan terör örgütü ve devlet ilişkilendirilmek istenmiş ve böyle bir konumda aktarılmıştır. Ayrıca bu haber metninde tarihselci bir bakış açısı üzerinden daha önce yaşanan bu tip olayların sorumluluğu da siyasal iktidara yüklenerek, haber söyleminde üretilmek istenen düşünce meşrulaştırılmıştır. Benzer şekilde haber metninde bu tip saldırıların barış sürecine zarar verdiği düşüncesi tercih edilen kelime kalıpları sayesinde 1srarla ön plana çıkarılırken, olayın sorumluluğu emniyet bürokrasisi içerisinden birilerine yüklenmek istenmiştir. $\mathrm{Bu}$ çerçevede haber metninin gramatik yapısında “devlet terörü” tanımlaması sık sık kullanılmıştır.

\section{Mart 2016 Ankara Güvenpark Terör Saldırısı}

Evrensel gazetesi 13 mart 2016 tarihinde Ankara Güvenpark’ta yaşanan terör saldırısını 15 Mart 2016 tarihli sayısında haberleştirmiştir. İlk sayfada manşetten yer verdiği haberin, iç sayfada da detaylıca ele alındığı görülmüsstür. 


\section{Makro Yapı Analizi:}

Haber başlığı için "BARIȘ OLMADAN GÜVENLİK OLMAZ" ifadesi kullanılmıştır. Başlığın hemen altında verilen haber spotunda ise "savaş politikalarına son verilmeli" cümlesinin aktarılması; haber başlığıla bütünleşik bir şekilde saldırının sorumlusu olarak varolan siyasal iktidar ve onun uygulamış olduğu politikalar işaret edilmiştir. Bu anlatı dizinini genel bir söylemsel çerçeveye dönüştürmek isteyen gazete, başlık ve spottan hemen sonra haber girişi için kullanmış olduğu "SORUMLU HÜKÜMET" alt başlığını ve hükümeti savaş politikası uygulamakla suçlayan tanımlamaları kullanmıştır. Bu haberin alt kısmında ve yanında yayınlanan diğer haberlerde de benzer konuların işlenmiş olması ve siyasi iktidarı "savaş politikaları uygulamaktan vazgeçmeye davet eden" söylemleri ön plana çıkaran haberlerin yayınlanmas1; gazete sayfasında bütüncül bir şekilde Ankara Güvenpark terör saldırılarının sorumlusu olarak varolan siyasal iktidarı işaret eden bir söylemin oluşmasını sağlamıştır. Haberin devamında kullanılan ikinci alt başlık ise "LAF ÇOK, İSTIFA YOK" olarak belirlenmiştir. Bu çerçevede haber metninin ana başlık, spot, ara başlık ve girişi bölümünde bütüncüllük arz eden bir anlatı yapısı tercih edilmiş, bu doğrultuda cümle yapıları oluşturulmuş ve dizilmiştir. Haber söyleminin inşasında başlık, spot ve giriş cümlelerinin oldukça etkili olduğu ve okuru oluşan söylemsel çerçeve doğrultusunda bir algılama sürecine sevk ettiği bilinmektedir. Bu bağlamda gazete bu yöntemi kullanarak faili belli bir terör saldırısında bile farklı bir haber söylemini üretip, üretilen bu söylemi meşrulaştırma çabasına girişmiştir. Bu haberde tercih edilen haber kaynak kullanımı da, haber metninde üretilmek istenen genel söylemsel çerçeve uygun bir şekilde gerçekleşmiştir. Gazete haber metninde üretmek istediği söylemi destekleyen çeşitli sivil toplum kuruluşu önderleri ve bazı akademisyenlerin açıklamalarına haber metni içerisinde geniş bir şekilde yer vermiştir. $\mathrm{Bu}$ bağlamda haber söylemi tek yönlü kaynak kullanımını nedeniyle tek boyutlu bir anlamsal çerçeve üzerinden meşrulaştırılmıştır. Aynı haber için tercih edilen görsel kullanımı da metinde üretilmek istenen tek boyutlu anlamsal kapanmayı destekleyen içerikleri barındıranlar arasından seçilmiştir. 


\section{Mikro Yapı Analizi:}

Haber söyleminin gramatik yapısı analiz edildiğinde; terör saldırısını tanımlamak için kullanılan kelimeler, sıfatlar, tamlamalar ve aktarım fiilleri sorunlu bir söylemsel çerçevenin oluşmasına neden olmuştur. Bu çerçeve olayın faillerini ve sorumlularını gizleyen, onun yerine "barış" gibi geniş bir tanımlama alanına sahip kavramı ön plana çıkaran bir yapıyı inşa etmiştir. Haber metninde tercih edilen cümle dizilişleri de olayın sorumlusunun gizlendiği ya da metinde ele alınmadığg bir sentaksın oluşmasına neden olmuştur. Bu haberin gramatik tasarımında olayın sorumlusu olarak siyasal iktidar, devlet yetkilileri ve güvenlik bürokrasisinin aktörleri 1srarla ön plana çıkarılmıştır. Ayrıca haber söylemini inşa ederken önemli bir etkiye sahip aktarım fiilleri de yoğun olarak kullanılmıştır. Özellikle olayın sorumlusu PKK terör örgütünün saldırısı ve açıklamaları pasif cümle kalıpları üzerinden aktarılırken; süreç içerisinde siyasal iktidarın, güvenlik bürokrasisinin ve devlet yetkililerinin aktarımları aktif cümle kalıpları üzerinden aktarılmıştır. Bu çerçevede haberin genel söylemsel çerçevesinde PKK'nın gerçekleştirmiş olduğu bir terör saldırısının aktarımında kullanılan kelime ve cümle yapıları sayesinde, sorumlu pozisyonuna devlet yetkilileri ve siyasiler yerleştirilmiştir.

\section{Sonuç ve Tartışma}

$\mathrm{Bu}$ çalışmada basın örgütlenmelerinin olayları ele alış süreçlerinde bu kuruluşlarının ekonomi-politiği, medya-iktidar ilişkileri ve ideolojik yapılarının belirlemiş olduğu genel yayın politikasının etkisi terör haberleri üzerinden ortaya konulmak istenmiştir. Bu kapsamda terör gibi evrensel bir tanımla üzerinden ele alınması gereken bir konunun, yine toplumsal hayatta şiddet gibi süreçler üzerinden siyaset üretme çabalarını reddeden sosyalist düşünsel birikim ekseninde kendi yayın politikalarına sahip olan Birgün ve Evrensel gazeteleri ele alınmıştır. Bu gazetelerin sosyalist bir çizgede şekillendirmiş ve siyasal iktidar karşıtlığı üzerine inşa etmiş oldukları genel yayın politikalarının; Ankara Tren Garı ve Ankara Güvenpark Bombalı Terör Saldırılarının temsilinde üretmiş oldukları haber söylemlerinin olay yönelimli olarak farklılıklar gösterdiği görülmüştür. Özellikle Ankara Tren Garı Saldırısında her iki gazete de terörizmi lanetleyen ve sorumluluğu siyasal iktidara yükleyen anlatı 
yapılarını ve haber söylemlerini tercih ettikleri bulgulanmıştır. Benzer tutum Ankara Güvenpark Bombalı Terör Saldırısı için geçerlilik göstermemektedir. Bu saldırının sunumunda haber söyleminde ön plana çıkarılmak istenen bunun bir terör saldırısı olduğu düşüncesi yerine, haber söyleminde 1srarlı bir șekilde güvenlik zafiyeti olduğu fikri işlenmiş ve sorumluluk yine siyasal iktidara yüklenmiştir.

Hem Birgün gazetesinin hem de Evrensel gazetesinin bu iki farklı terörist eylemde terör eylemini gerçekleştiren ve farklı ideolojik yapılara sahip terör örgütlerine göre haber sunumlarının ve haber söylemlerinin eyleyen yönelimli olarak farklılıklar gösterdiği görülmüştür. Gazeteler dini motifli DAİŞ terör örgütü tarafından gerçekleştirilen Ankara Tren Garı Terör Saldırısı'nı 'halkların kardeşliği, medeniyetlerin ittifakı ve barış' söylemleri altında 'katliam' olarak niteleyerek manşetlerine taşırken, terörizmle varolan siyasal iktidar ve onun politikalarını terörle ilişkilendiren temsiller haber söyleminde üretilmiştir. Ayrıca haber söylemlerinde olayın sorumluluğunu doğrudan varolan siyasal iktidara yükledikleri de görülmektedir. Aynı gazeteler PKK terör örgütünün şehir yapılanmasını temsil eden kolu TAK tarafindan gerçekleştirilen Ankara Güvenpark terörist saldırısını ise sıradan bir 'patlama' olarak aktarırken yaşanan terör saldırısına atıf yaparak terör örgütünün propaganda faaliyetlerini gerçekleştiren 'gönüllü bir araç' olarak işlev görmekten kaçınmamışlardır. Dolayısıyla gazetelerin terörist saldırılar karşısında standart bir bakış açısına sahip olmanın aksine kendi ideolojik bakış açıları ve yayın politikaları doğrultusunda 'benim teröristim' 'senin teröristin' gibi çifte standartlı bir yaklaşım sergileyerek haber söylemlerini inşa ettikleri görülmüştür.

Sonuç olarak medyanın farklı bakış açılarına ve farklı ideolojik yaklaşımlara sahip olması ne kadar doğal ve sıradan bir durum ise; terörist saldırıları da haberleștirerek okur kitleye aktarması son derece doğal bir durumdur. Bu bağlamda ifade hürriyeti kapsamında medyanın sorgulayıcı bir tavır sergilemesi de sorunsal olarak değerlendirilmemelidir. Fakat gelişmiş demokrasilerde bile ifade hürriyetinin sınırsız olmadığı bilinen bir gerçektir ve demokratik tutum içinde ifade hürriyetinin de sinırlı olduğu bazı evrensel durumlar ya da tanımlar söz konusudur. Bu bağlamda ifade 
hürriyeti adı altında demokratik hukuk yasaları ve kamu yararı ihlal edilmeden, basın kuruluşlarının hangi ideolojik yapıya sahip olursa olsun kurumun ve çalışanlarının terör saldırılarının bir hedefí olabileceği gerçeği göz önünde tutularak terörün her türlüsüne karşı ortak bir tavır sergileyebilme bilincine ve fiiline sahip olabilmesi gerekmektedir. Ayrıca bu noktada gazetenin yayın politikası ele alındığında, habere konu olan eylemlerin failleri ve haber örgütlenmeleri arasında ideolojik yakınlıkların olduğu durumlarda; terör saldırılarının haberleştirilmesi yayın politikası doğrultusunda ideolojik bir eğilim kazanmaktadır. Bu gibi durumlarda ideolojik yakınlaşmalar neticesinde terör saldırılarının tam olarak terör bağlamında taşınmadan haberleştirildiği görülmektedir. $\mathrm{Bu}$ amaçla basın kuruluşları insani duyarlılığı törpüleyici, kamu vicdanını zedeleyici, ölümleri haklılaştırıcı ve şiddeti meşrulaştırıcı ideolojik perspektifler üzerinden yayın politikaları belirlememeli ve bu tip yayın politikalarından uzak durmalıdır. Bu sayede basın kuruluşları terör saldırılarının temsilinde kullandıkları dil yapıları ve haber söylemleri yoluyla terör örgütlerinin propaganda aracı olmak yerine, ideoloji ayrımı gözetmeksizin tüm insanlığı hedef alan terörizmden uzaklaşarak kamu yararına ve demokratik hukuka hizmet etmiş olacaklardır. 


\section{Kaynakça}

Arık, B. (2006). Illetişim Yazıları, Konya: Tablet Kitabevi.

Avşar Z. (2009). “Terörizmle Küresel Mücadele Stratejisi İçinde Medyanın Yeri Ne Olmalı?", Terör ve Haber Söylemi, M. Şeker ve T. Şeker (Ed.), Literatürk Yayınları, s. 6188.

Bal, İ. (2006). Terörizm: Terör Nedir? Neden Terörist Olunur?, Ankara: Siyasal Basım Yayın Dağıtım.

Bennett, L. (2000). Politik Illlüzyon ve Medya, İstanbul: Nehir Yayınları.

Bulut, S. \& Yaylagül, L. (2004). “Türkiye'deki Yazılı Basında Yargıtay ve Mafya İlişkisine Yönelik Haberler”, İletişim, Sayı: 19, s. 119-142.

Combs, C. C. (1997). Terrorism in the Twenty-First Century, New Jersey: Prentice Hall.

Çatal Ö. (2006). "KKTC Radyo ve Televizyon Kanallarının Yayın Politikaları, Sahiplik Yapısı ve Haber Üretim Süreçleri”, Küresel İletişim Dergisi, Sayı:1, Bahar, s.111.

Demir, S. (2013). "Türkiye'de 2001 Yılı Sonrasında Medya-Iktidar Ilişskileri ve Gazeteci Pratiklerine Yansıması, (Yayımlanmamış Yüksek Lisans Tezi). Ankara Üniversitesi Sosyal Bilimler Enstitüsü, Ankara.

Devran, Y. (2010). Haber \& Söylem \& İdeoloji, İstanbul: Başlık Yayın Grubu.

Devran, Y. (2015). "Medya ve Terör Sorunsal1”, Gümüşhane Üniversitesi Illetişim Fakültesi Elektronik Dergisi, Sayı:2, s. 85-95.

Duran, R. (1999). Burası Dünya Polis Radyosu, İstanbul: Yapı Kredi Yayınları.

Eagleton T, (2005). İdeoloji, (M. Özcan, Çev.), İstanbul: Ayrıntı Yayınları.

Hanlin, B. (1998). "Gazete Sahipleri, Editörler ve Gazeteciler", Medya ve Gazetecilikte Etik Sorunlar, A. Belsey and R Chadwick (Ed.), (N. Türkoğlu Çev.), İstanbul: Ayrıntı Yayınları, s. 51-66. 
İnal A. (1994). "Haber Metinlerine Eleştirel Bir Bakış: Temel Sorunlar ve Örnek Çalışmalar”, Ankara Üniversitesi İletişim Fakültesi Dergisi Yıllık, s. 135-163.

İnal A. (1996). Haberi Okumak, İstanbul: Temuçin Yayınları.

Karaduman, S. \& Batu, M. N. (2011). "Televizyon Haberlerinde Terörizm Olgusunun TRT’nin Haber Söylemi Bağlamında İncelenmesi”, Selçuk Üniversitesi Sosyal Bilimler Enstitüsü Dergisi, Say1 25, s. 359- 374.

Kavoğlu, S. (2017). "Demokratik Açılım ve Barış Süreci” Bağlamında "Akil İnsanlar Heyeti" ve Ulusal Basında Yansımaları, Uluslararası Hakemli İletişim ve Edebiyat Araştırmaları Dergisi, Sayı 15, s. 196-219.

Korkmaz, G. (1999). “Terör Olaylarının Medyaya Yansıması”, Doğu Anadolu'da Güvenlik ve Huzur Sempozyumu Kitapçığı, Elazığ: Fırat Üniversitesi Yayınları, s. 228-241.

Korkmaz, G. (2006). “Tanımı Sorunlu Bir Kavram: Terör”, Polis Dergisi Türkiye ve Terörizm Özel Sayısı, Ankara: TBB Yayınları.

Küçüközyiğit, U. (2014). “Gazetelerin Haber Karar Süreçleri ve Haber Kararlarını Etkileyen Faktörler: Karşılaştırmalı Bir Saha Araştırması", İletişim Kuram ve Araştırma Dergisi, Say1 39, s. 26-47.

Özdemir, Z. (2016). "Rehine Krizi ve Anaakım Medyanın Terör Eylemlerine Yaklaşımı", Akademik Sosyal Araştırmalar Dergisi, Sayı: 23, s. 237-254.

Schaffert, R. W. (1992). Media Coverage and Political Terorist: A Quantitative Analysis, New York: Praeger.

Schneider, W. and Raue, P. J. (2002). Gazetecinin El Kitabl, İstanbul: İstanbul Üniversitesi İletişim Fakültesi Yayınları.

Shoemaker, P. J. and Reese, S. D. (1996). Mediating The Message: Theories Of Influences on Mass Media Content, New York: Longman.

Şeker, M. (2009). "Dağlıca Baskını Haberlerinin Söylemi”, Terör ve Haber Söylemi, M. Şeker ve T. Şeker (Ed.), İstanbul: Literatürk Yayınevi, s. 89-156.

Şeker T. ve Şeker M. (2011). "Televizyon Haberlerinde Söylem: 29 Mart 2009 Yerel Seçimler Örneği”, Selçuk Üniversitesi Türkiyat Araştırmaları Dergisi, Sayı:30, s. 515-552. 
T1lıç, L. D. (2001). 2000’ler Türkiye’sinde Gazetecilik ve Medyayı Anlamak, İstanbul: Su Yayınları.

Topçuoğlu, A. (1992). “Terör Karşısında Kitle İletişim Araçları”, Yeni Forum Dergisi, Haziran Sayısı, s. 15-23.

van Dijk, T. (2007). "Medya İçerikleri, Bir Söylem Olarak Haberin Disiplinler Arası Çözümlenmesi”, Medya Metinlerini Çözümlemek, G. Atabek ve Ümit Atabek (Ed.), (Ü. Atabek, Çev.), Siyasal Kitabevi Yayınları, Ankara, s.165-184.

van Dijk, T. (2003). "Critical Discourse Analysis", The Handbook of Discourse Analysis, Deborah Schiffrin \& et al. (Ed.), Oxford: Blakwell Publishing, p. 352-372.

van Dijk, T. (1988). News as Discourse, New Jersey: Lawrence Earlbaum Associates Publication.

Wood, L. \& Kruger, R. O. (2000). Doing Discourse Analysis: Methods for Studying Action in Talk and Text, Londan: Sage Publication.

Yaylagül, L. (2006). Kitle İletişim Kuramları: Egemen ve Eleştirel Yaklaşımlar, Ankara: Dipnot Yayınları.

Yücel, Ö. (2011). Televizyonlarda Terör, Irkçıllk ve Nefret İçerikli Yayınlar, Uzmanlık Tezi, Ankara: Radyo Televizyon Üst Kurulu 